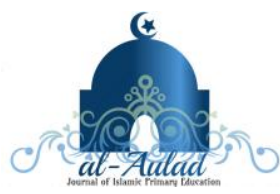

\title{
MENINGKATKAN HASIL BELAJAR KOGNITIF BAHASA ARAB MELALUI COOPERATIVE LEARNING TIPE TEBAK KATA
}

\author{
Rin-Rin Rosmayanti ${ }^{1}$, Nanang Kosim ${ }^{2}$

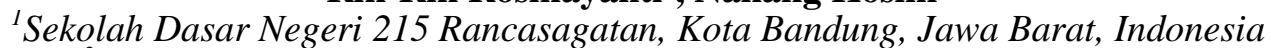 \\ ${ }^{2}$ Jurusan Pendidikan Bahasa Arab, UIN Sunan Gunung Djati, Indonesia \\ orindt@gmail.com
}

Naskah diterima: tanggal 17 Juli 2018, direvisi: tanggal 30 Juli 2018, diterbitkan: tanggal 31 Oktober 2018

\begin{abstract}
The purpose of this research was conducted to find out the results of the cognitive skill, especially in the subjects of Arabic language. This research analysed before and after cognitive skill using the model of cooperative learning, and identified the activites with the approach in grade III Madrasah Ibtidaiyah (MI) Nurul Huda Bandung, West Jawa, Indonesia. This research uses Classroom Action Research (CAR), that have been implemented in two cycles. Based on the results of the data processing, obtained mean of cognitive learning skill of students before using the model of cooperative learning is 54.09 (27\%). The application of cooperative learning in cycle I gained an average rating of teacher's activities amounted to $72 \%$ and students is $67 \%$, respectively. Furthermore, teacher and students activities in cycle II witnessed to increase dramatically, the former is $94 \%$ and later is $92 \%$, respectively. The cognitive skill of students in MI after using cooperative learning on cycle I gained an average rating of 75 (86\%), and in cycle II derived to 95 (87.7\%). This indicate that model of cooperative learning is able to enhance cognitive skill of students on Arabic subject in MI Nurul Huda Bandung.
\end{abstract}

Keywords: Cooperative Learning, activites of learning, cognitive skill

\begin{abstract}
ABSTRAK
Penelitian ini dilakukan tujuan untuk mengetahui hasil belajar kognitif siswa pada mata pelajaran bahasa Arab sebelum dan sesudah menggunakan model cooperative learning tipe tebak kata dan penerapannya pada mata pelajaran bahasa Arab di kelas III MI Nurul Huda Kota Bandung. Penelitian ini menggunakan Penelitian Tindakan Kelas yang telah dilaksanakan selama dua siklus. Berdasarkan hasil pengolahan data, diperoleh nilai rata-rata hasil belajar kognitif siswa sebelum menggunakan model cooperative learning tipe tebak kata sebesar 54,09 (27\%). Penerapan model cooperative learning tipe tebak kata pada siklus I diperoleh nilai rata-rata aktivitas guru sebesar $72 \%$ dan siswa sebesar $67 \%$ dan pada siklus II diperoleh nilai rata-rata aktivitas guru sebesar $94 \%$ dan siswa $92 \%$. Hasil belajar kognitif siswa sesudah menggunakan model cooperative learning tipe tebak kata pada siklus I diperoleh nilai rata-rata sebesar $75(86 \%)$ dan pada siklus II diperoleh nilai rata-rata $87,7(95 \%)$. Hal ini membuktikan bahwa model cooperative learning tipe tebak kata mampu meningkatkan hasil belajar kognitif siswa pada mata pelajaran Bahasa Arab di MI Nurul Huda Kota Bandung.
\end{abstract}

Kata Kunci: Cooperative learning, hasil belajar, kognitif

\section{PENDAHULUAN}

Pendidikan merupakan hal yang sangat penting dalam kehiudupan manusia, karena dengan pendidikan manusia dapat membina dirinya untuk mencapai ke kedewasaan yang lebih baik. Seiring berkembangnya zaman pengertian pendidikan terus mengalami perkembangan, meskipun memiliki arti yang tidak jauh beda. Menurut Langeveld dalam Hasbullah(2005: 2) pendidikan adalah setiap usaha yang diberikan dari orang dewasa kepada anak agar anak tersebut dapat mencapai ke kedewasaanya dan dapat cakap 
melaksanakan tugas hidupnya secara mandiri. Sedangkan menurut Jhon Dewey dalam Hasbullah (2005: 2) pendidikan merupakan suatu proses pembentukan keterampilan secara intelektual dan emosional yang bermanfaat bagi lingkungan dan sesama manusia. Dari pengertian tersebut dapat disimpulkan bahwa pendidikan merupakan suatu usaha yang dilakukan oleh seseorang yang ahli untuk mendidik, membimbing maupun mengarahkan manusia agar mencapai perubahan yang lebih baik dalam sikap, pengetahuan maupun perilakunya bagi dirinya maupun lingkungan sekitarnya dan untuk mencapai tujuan pendidikan.

Tujuan pendidikan merupakan hal-hal yang harus dicapai dalam dunia pendidikan dan dapat dicapai salah satunya melalui lembaga madrasah. Madrasah sebagai salah satu lembaga pendidikan formal yang berbasis keagamaan serta mencetak kualitas generasi cerdas, inovatif kreatif, berbudi pekerti luhur, tanggap dan bertakwa kepada Tuhan Yang Maha Esa (Trianto, 2013). Untuk mencapai tujuan pendidikan di madrasah tersebut salah satu mata pelajaram yang harus dipelajari di madrasah yaitu mata pelajaran Bahasa Arab.

Menurut Keputusan Menteri Agama No. 165 tahun 2014 pembelajaran bahasa Arab di madrasah merupakan sebagai pengantar untuk memahami ajaran Islam. Ajaran Islam tersebut dapat dipahami dan dipelajari secara benar dan mendalam dari sumber utamanya yaitu al-qur'an dan hadis serta yang lainnya yang berbahasa Arab. Bahasa Arab merupakan mata pelajaran bahasa yang diarahkan untuk mendorong, membimbing, mengembangkan, dan membina kemampuan serta menumbuhkan sikap positif terhadap bahasa Arab, baik reseptif maupun produktif. Kemampuan reseptif adalah kemampuan untuk memahami pembicaraan orang lain dan memahami bacaan. Kemampuan produktif yaitu kemampuan menggunakan bahasa sebagai alat komunikasi baik secara lisan maupun secara tertulis.bahasa Arab di madrasah dipersiapkan untuk pencapaian kompetensi dasar berbahasa, yang mencakup empat keterampilan berbahasa yang diajarkan secara integral, ayitu menyimak, berbicara, membaca, dan menulis. Mata pelajaran bahasa Arab merupakan salah satu mata pelajaran yang dianggap sebagian siswa sulit, membosankan dan menjenuhkan. Namun, hal itu dapat diubah oleh guru bahasa Arab menjadi mata pelajaran yang mudah, menyenangkan dan tidak membosankan.

Berdasarkan hasil observasi di MI Nurul Huda Kota Bandung, ditemukan permasalahan dalam proses pembelajaran, khususnya di kelas III pada mata pelajaran bahasa Arab, terdapat sebagian besar siswa yang masih memiliki nilai bahasa Arab di bawah standar nilai kriteria ketuntasan minimal (KKM) yang telah ditentukan yaitu 65 . Berdasarkan keterangan guru, respon siswa terhadap proses pembelajaran pun kurang baik sehingga hasil belajar kognitif siswa rendah. Dari keadaan yang ditemukan dilapangan, perlu adanya perubahan dalam penggunaan model pembelajaran yang mampu menarik siswa sehingga semangat untuk belajar dan dapat meningkatkan hasil belajar kognitif siswa pada mata pelajaran bahasa Arab.

Model pembelajaran adalah suatu gambaran yang aktual sehingga memungkinkan seseorang atau sekelompok orang mencoba melakukan tindakan dengan model itu (Suprijono, 2009). Model pembelajaran adalah suatu rencana atau pola untuk membentuk kurikulum, merancang bahan-bahan pembelajaran dan membimbing pembelajaran di kelas(Rusman, 2010). Berdasarkan pengertian diatas dapat disimpulkan bahwa model pembelajaran yaitu suatu pola yang dapat dipilih oleh guru dan digunakan dalam proses pembelajaran yang dapat membantu dalam mengatur materi pembelajaran serta memberikan petunjuk kepada guru dalam melaksanakan proses pembelajaran tersebut.

Model cooperative learning adalah suatu model pembelajaran yang dilakukan dengan sistem belajar dan bekerja dalam kelompok-kelompok kecil siswa secara 
kolaboratif sehingga meningkatkan gairah siswa dalam belajar (Taniredja, 2014). Model cooperative learning adalah suatu model pembelajaran dimana pada saat proses pembelajaran peserta didik belajar dengan cara bekerja kelompok-kelompok kecil 4-6 orang dengan anggota kelompok yang heterogen (Isjoni, 2010). Berdasarkan pengertian tersebut dapat disimpulkan bahwa model cooperative learning adalah model yang dilaksanakan secara berkelompok sehingga secara berkolaboratif dan integratif siswa dapat bekerjasama dalam menyelesaikan permasalahan yang telah diberikan oleh guru.

Salah satu model coopeartive learning yang dapat dijadikan solusi permasalahan tersebut, ialah menggunakan model cooperative learning tipe tebak kata. Model cooperative learning tipe tebak kata adalah menebak suatu kata yang telah ditentukan dengan menyebutkan kata-kata tertentu atau petunjuk tertentu sampai kata yang disebutkan benar (Said, 2015). Model tebak kata ini merupakan sebuah model pembelajaran yang berbasis permainan sesuai dengan karakter siswa dengan menggunakan media kartu tekateki yang berpasangan dengan kartu yang berisi jawaban dari kartu teka-teki tersebut (Suprijono, 2009). Berdasarkan pengertian tersebut dapat disimpulkan bahwa model cooperative learning tipe tebak kata merupakan model pembelajaran yang dilaksanakan seperti permainan sehingga sesuai dengan karakter siswa di MI dan dilakukan secara berpasangan dengan temannya menggunakan media kartu berupa kartu berisi teka-teki dan kartu yang berisi jawaban dari teka-teki tersebut.

Model cooperative learning tipe tebak kata memiliki keunggulan yaitu, dengan proses tebak kata siswa akan mempunyai kekuasaan bahaa, pembelajaran bersifat menyenangkan sehingga menarik siswa untuk mencoba dan menarik untuk setiap siswa untuk mencobanya, serta memudahkan dan menanamkan konsep pelajaran dalam ingatan siswa. Sedangkan kelemahan dari model cooperative learning tipe tebak kata yaitu, memerlukan waktu yang lama sehingga materi sulit tersampaikan semua dan tidak semua siswa bisa maju karena waktunya terbatas (Ferianti, 2016).

Penelitian ini dilakukan dengan tujuan untuk mengetahui hasil belajar kognitif siswa sebelum menggunakan model cooperative learning tipe tebak kata, untuk mengetahui penerapan model cooperative learning tipe tebak kata pada setiap siklusnya dan untuk mengetahui hasil belajar kognitif siswa sesudah menggunakan model coopeartive learning tipe tebak kata. Manfaat dari penelitian ini adalah dapat dijadikan alternatif model pembelajaran pada mata pelajaran bahasa Arab dan sebagai gambaran bagi guru dalam menerapkan model cooperative learningi tipe tebak kata dalam pembelajaran bahasa Arab. Selain itu, penelitian ini bermanfaat untuk menciptakan suasana belajar yang lebih menyenangkan sehingga meningkatkan keatifan siswa dalam proses pembelajaran di kelas dan dapat meningkatkan hasil belajar kognitif pada mata pelajaran bahasa Arab siswa.

\section{METODOLOGI}

Penelitian ini menggunakan metode penelitian tindakan kelas, dimana peneliti bertindak langsung sebagai guru yang mengajar di kelas bertujuan untuk meningkatkan kualitas pembelajaran dan hasil belajar kognitif siswa. Penelitian ini dilakukan sebanyak dua siklus dan setiap siklus terdiri atas dua tindakan. Setiap tindakan terdiri dari empat langkah yaitu perencanaan, pelaksanaan, observasi dan refleksi. Penelitian ini dilakasanakan pada bulan April 2018, di Madrasah Ibtidaiyah Nurul Huda Kota Bandung. Subjek utama penelitian ini adalah siswa kelas III berjumlah 22, terdiri dari 14 orang lakilaki dan 8 orang perempuan. Jenis data penelitian dibagi dua yaitu data kuantitatif dan data kualitatif. Data kuantitatif adalah berupa numberik yang diperoleh berdasarkan tes tulis pilihan ganda, lembar penilaian ini bertujuan untuk mengetahui sejauh mana tingkat 
penguasaan materi yang telah diberikan kepada siswa. Data kualitatif adalah data yang diperoleh dari kondisi objektif proses pembelajaran di kelas. Teknik pengumpulan data yang digunakan dalam penelitian ini yaitu Tes dan Observasi.

Teknik analisis data tes objektif atau pilihan ganda dapat dilihat dari hasil penilaian tes yang diberikan setiap akhir siklus proses pembelajaran dengan menggunakan modl coopertaive learning tipe tebak kata. Penilaian ini untuk mengukur tingkat pemahaman dan penguasaan materi yang telah diberikan. Untuk mengetahui peningkatan hasil belajar kognitif siswa pada setiap siklusnya dengan menggunakan rumus sebagai berikut:

Ketuntasan individu: $=\frac{\text { Skor yang dicapai siswa }}{\text { Skor maksimal }} \times 100 \%$

Tabel 1. Kriteria Ketuntasan Belajar Individu

\begin{tabular}{|c|c|c|}
\hline No & Persentase Keterlaksanaan & Kriteria \\
\hline 1 & Siswa yang $\leq 65$ & Tidak tuntas \\
\hline 2 & Siswa yang $\geq 65$ & Tuntas \\
\hline
\end{tabular}

Sumber: Hindun, 2015

Ketuntasan klasikal: $=\frac{\text { Jumlah siswa yang memperoleh tingkat ketuntasan } \geq 65}{\text { jumlah siswa seluruhnya }} \times 100 \%$

Tabel 2. Kriteria Ketuntasan Belajar Klasikal

\begin{tabular}{|c|c|c|}
\hline No & Persentase Keterlaksanaan & Kriteria \\
\hline 1 & Persentase ketuntasan $\leq 85 \%$ & Perbaikan \\
\hline 2 & Persentase ketuntasan $\geq 85 \%$ & Tidak Perbaikan \\
\hline
\end{tabular}

Sumber: Hayati, 2013

Sedangkan pengolahan data observasi dapat dilihat dari persentase rata-rata aktivitas guru dan aktivitas siswa. Hasil observasi dapat dihitung dengan menjumlahkan skor yang diperoleh, kemudian dihitung rata-ratanya. Untuk mengetahui hasil observasi guru dan siswa menggunakan rumus:

Nilai rata-rata $=\frac{\text { Jumlah skor yang diperoleh }}{\text { Jumlah item soal }} \times 100 \%$

(Sumber: Susilawati, 2010)

Tabel 3. Kriteria Tingkat Aktivitas Guru dan Siswa

\begin{tabular}{|c|l|c|}
\hline No & \multicolumn{1}{|c|}{ Presentase Keterlaksanaan } & Kriteria \\
\hline 1 & Nilai rata-rata $75 \%-100 \%$ & Sangat Baik \\
\hline 2 & Nilai rata-rata $50 \%-75 \%$ & Baik \\
\hline 3 & Nilai rata-rata $25 \%-50 \%$ & Cukup \\
\hline 4 & Nilai rata-rata $0 \%-25 \%$ & Kurang Baik \\
\hline
\end{tabular}

Sumber: Hindun,2015

\section{HASIL DAN DISKUSI}

a. Hasil Belajar Kognitif Siswa Pada Mata Pelajaran Bahasa Arab Sebelum Menggunakan Model Cooperative Learning Tipe Tebak Kata

Kegiatan diawali dengan dilakukannya kegiatan pra siklus dengan tujuan untuk mengetahui kondisi awal objek yang diteliti dan untuk mengetahui nilai hasil belajar kognitif siswa sebelum menggunakan model cooperative learning tipe tebak kata. Pembelajaran bahasa Arab pada pra siklus yaitu tentang materi keadaan kebun, guru menggunakan metode ceramah dan tanya jawab dalam proses pembelajarannya. Pada 
saat proses pembelajaran guru menggunakan media berupa gambar tentang keadaan kebun, karena tidak semua siswa mempunyai buku pegangan bahasa Arab. Kemudian guru memberikan contoh bacaan mufradat yang benar kemudian siswa mengulang kembali apa yang diucapkan guru secara berulang-ulang. Di akhir pembelajaran, guru menyimpulkan materi yang dibahasnya. Kondisi yang terjadi saat pembelajaran bahasa Arab berlangsung antara lain siswa cenderung hanya membaca dan menulis saja materi yang dipelajari. Hal ini disebabkan karena metode atau model pembelajaran yang digunakan tidak variatif sehingga siswa kurang aktif dalam proses pembelajaran serta respon siswa pun kurang pada saat guru menjelaskan materi pembelajaran. Oleh sebab itu, kondisi siswa dalam pembelajaran tersebut berdampak pada penguasaan materi pembelajaran dan akhirnya nilai hasil belajar kognitifnya pun rendah atau masih di bawah kriteria ketuntasan minimal (KKM).

Tabel 4. Ketuntasan hasil belajar kognitif siswa Pra Siklus

\begin{tabular}{|c|c|c|}
\hline Persentase & Jumlah Siswa & Kriteria \\
\hline Siswa yang bernilai $\geq 65$ & 6 orang & Tuntas \\
\hline Siswa yang bernilai $\leq 65$ & 16 orang & Tidak tuntas \\
\hline
\end{tabular}

Adapun presentase hasil belajar kognitif siswa pra siklus dapat dilihat dalam bentuk diagram, pada grafik 1 sebagai berikut:

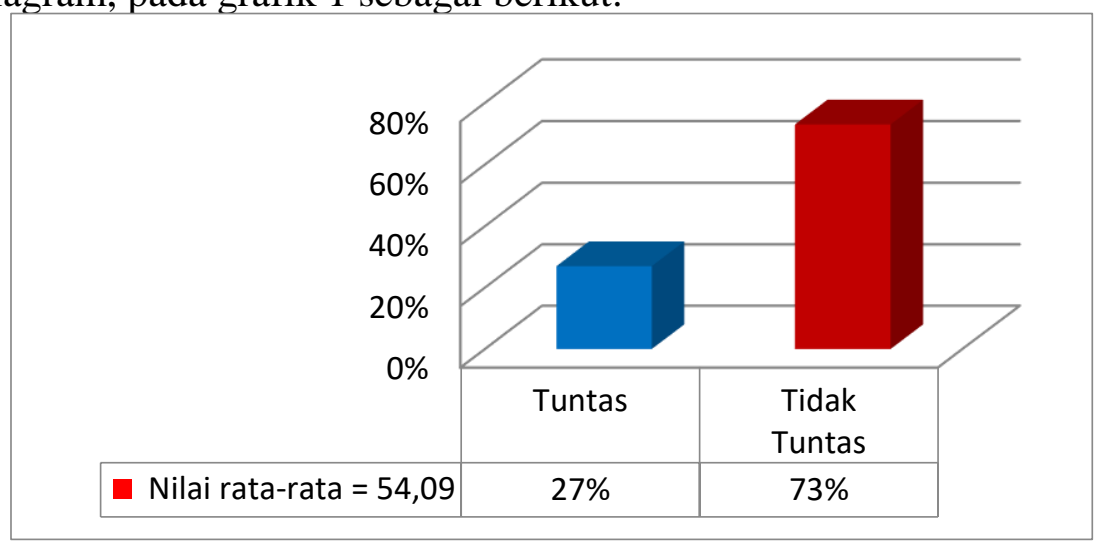

Grafik 1. Grafik Presentase Hasil Belajar Kognitif Pra siklus

Berdasarkan Tabel 4 dan Grafik 1 menunjukan bahwa hasil belajar kognitif siswa sebelum menggunakan model cooperative learning tipe tebak kata memperoleh nilai rata-rata sebesar 54,09 dengan persentase $27 \%$, dengan kriteria tuntas dan $73 \%$ dengan kriteria tidak tuntas. Berdasarkan hal tersebut maka hasil belajar kognitif siswa dapat dikatakan masih rendah.

b. Penerapan Model Cooperative Learning Tipe Tebak Kata Pada Mata Pelajaran Bahasa Arab Tiap Siklus

Aktivitas guru dan siswa selama menggunakan model cooperative learning tipe tebak kata mengalami peningkatan tiap siklusnya. Pada siklus I aktivitas guru dan aktivitas siswa yang dicapai masih kurang maksimal dikarenakan masih kurangnya aktivitas belajar siswa dengan menggunakan media yang diterapkan oleh guru, karena ruang belajar yang kurang efektif dan siswa masih bingung dengan media dan model yang digunakan serta guru belum bisa mengkondisikan kelas dengan baik sehingga siswa kurang memerhatikan ketika temannya maju ke depan kelas. Oleh karena itu, aktivitas guru dan siswa masih harus ditingkatkan pada siklus II agar seluruh tahapan dapat tersampaikan secara maksimal. 
Aktivitas guru dan aktivitas siswa pada pembelajaran siklus II mengalami peningkatan dari pembelajaran siklus I. Hal ini dikarenakan siswa mulai nyaman dan tidak asing dengan model yang digunakan sehingga kegiatan pembelajaran pun jadi menyenangkan dan materi pembelajaran tersampaikan dengan maksimal.

Perbedaan proses pembelajaran pada siklus I dan siklus II adalah penggunaan media. Peneliti berinisiatif untuk menggunakan media berupa karton pada siklus II ttindakan 1 dan tindakan 2 yang berisi gambar terkait mufradat yang dipelajari, khususnya karena melihat kondisi siswa yang tidak semua mempunyai buku paket bahasa Arab sehingga mempersulit siswa untuk belajar. Selebihnya rangkaian proses pembelajaran dari siklus I dan siklus II sama saja seperti dengan prosedur pembelajaran dan model pembelajaran yang digunakan.

Tabel 5. Kriteria tingkat aktivitas guru dan siswa

\begin{tabular}{|c|l|c|}
\hline No & \multicolumn{1}{|c|}{ Presentase Keterlaksanaan } & Kriteria \\
\hline 1 & Nilai rata-rata $75 \%-100 \%$ & Sangat Baik \\
\hline 2 & Nilai rata-rata $50 \%-75 \%$ & Baik \\
\hline 3 & Nilai rata-rata $25 \%-50 \%$ & Cukup \\
\hline 4 & Nilai rata-rata $0 \%-25 \%$ & Kurang Baik \\
\hline
\end{tabular}

Persentase Aktivitas guru pada siklus I tindakan 1 dapat dilihat pada grafik berikut:

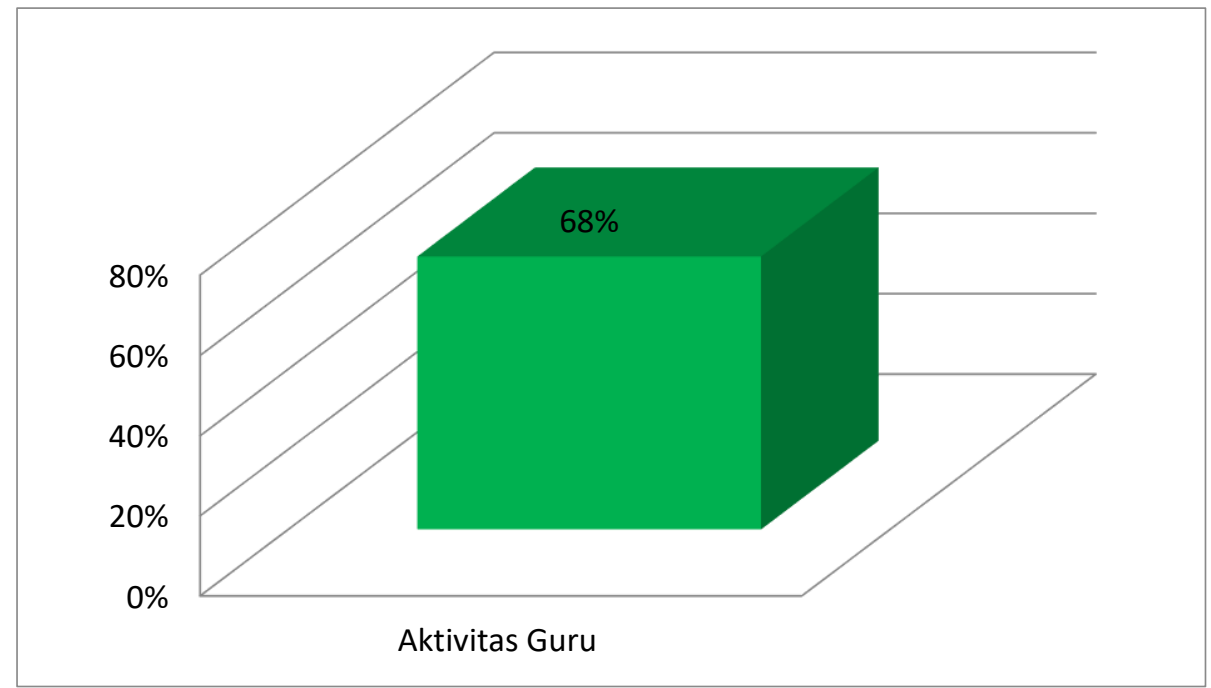

Grafik 2. Grafik Persentase Aktivitas Guru Siklus I Tindakan 1

$$
\text { Nilai rata-rata } \begin{aligned}
(\mathrm{NR}) & =\frac{\text { skor yang diperoleh }}{\text { Skor maksimal }} \times 100 \% \\
& =\frac{52}{76} \times 100 \%=68 \%
\end{aligned}
$$


Persentase aktivitas siswa pada siklus I Tindakan 1 dapat dilihat pada grafik berikut:

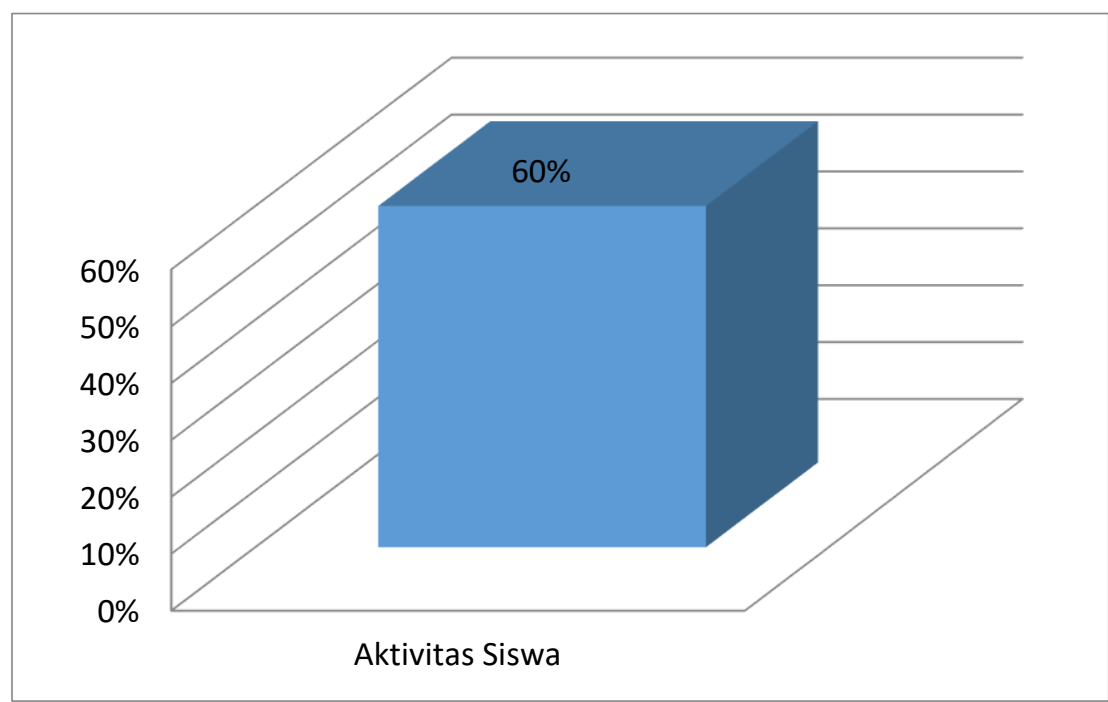

Grafik 3. Grafik Persentase Aktivitas Siswa Siklus I Tindakan 1

$$
\begin{aligned}
\text { Nilai rata-rata }(\mathrm{NR})= & \frac{\text { skor yang diperoleh }}{\text { Skor maksimal }} \times 100 \% \\
& =\frac{24}{40} \times 100 \%=60 \%
\end{aligned}
$$

Persentase aktivitas guru pada siklus I tindakan 2 dapat dilihat pada grafik berikut:

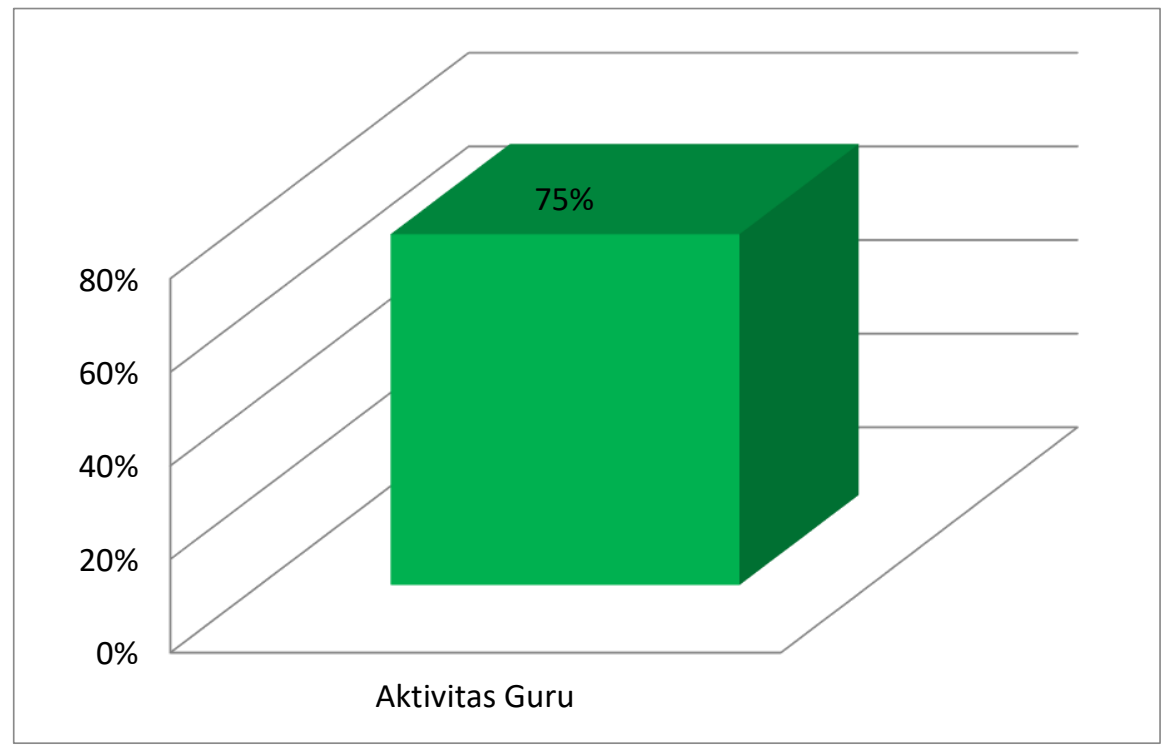

Grafik 4. Grafik Persentase Aktivitas Guru Siklus I Tindakan 2

$$
\begin{aligned}
\text { Nilai rata-rata }(\mathrm{NR}) \quad= & \frac{\text { skor yang diperoleh }}{\text { Skor maksimal }} \times 100 \% \\
& =\frac{57}{76} \times 100 \%=75 \%
\end{aligned}
$$


Persentase aktivitas siswa pada siklus I tindakan 2 dapat dilihat pada grafik berikut:

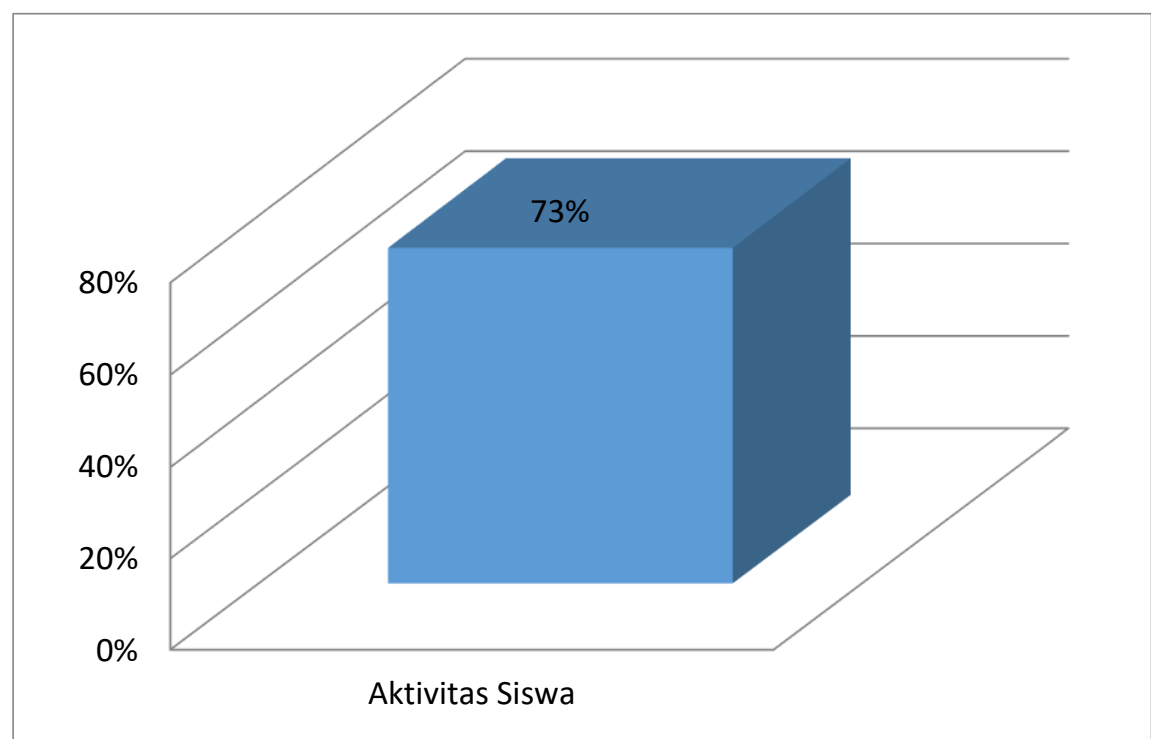

Grafik 5. Grafik Persentase Aktivitas Siswa Siklus I Tindakan 2

$$
\begin{aligned}
\text { Nilai rata-rata }(\mathrm{NR}) \quad= & \frac{\text { skor yang diperoleh }}{\text { Skor maksimal }} \times 100 \% \\
& =\frac{29}{40} \times 100 \%=73 \%
\end{aligned}
$$

Persentase aktivitas guru pada siklus II tindakan 1 dapat dilihat pada grafik berikut:

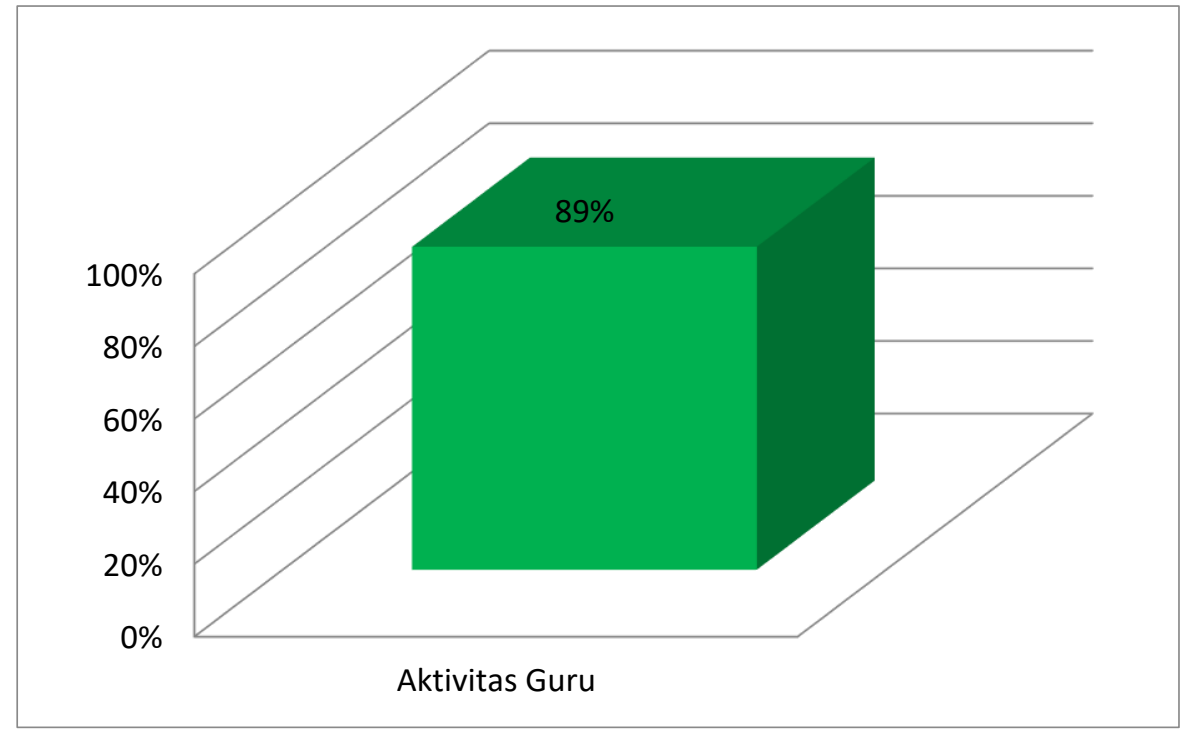

Grafik 6. Grafik Persentase Aktivitas Guru Siklus II Tindakan 1

$$
\begin{aligned}
\text { Nilai rata-rata }(\mathrm{NR}) \quad= & \frac{\text { skor yang diperoleh }}{\text { Skor maksimal }} \times 100 \% \\
& =\frac{68}{76} \times 100 \%=89 \%
\end{aligned}
$$


Persentase aktivitas siswa pada siklus II tindakan 1 dapat dilihat pada grafik berikut:

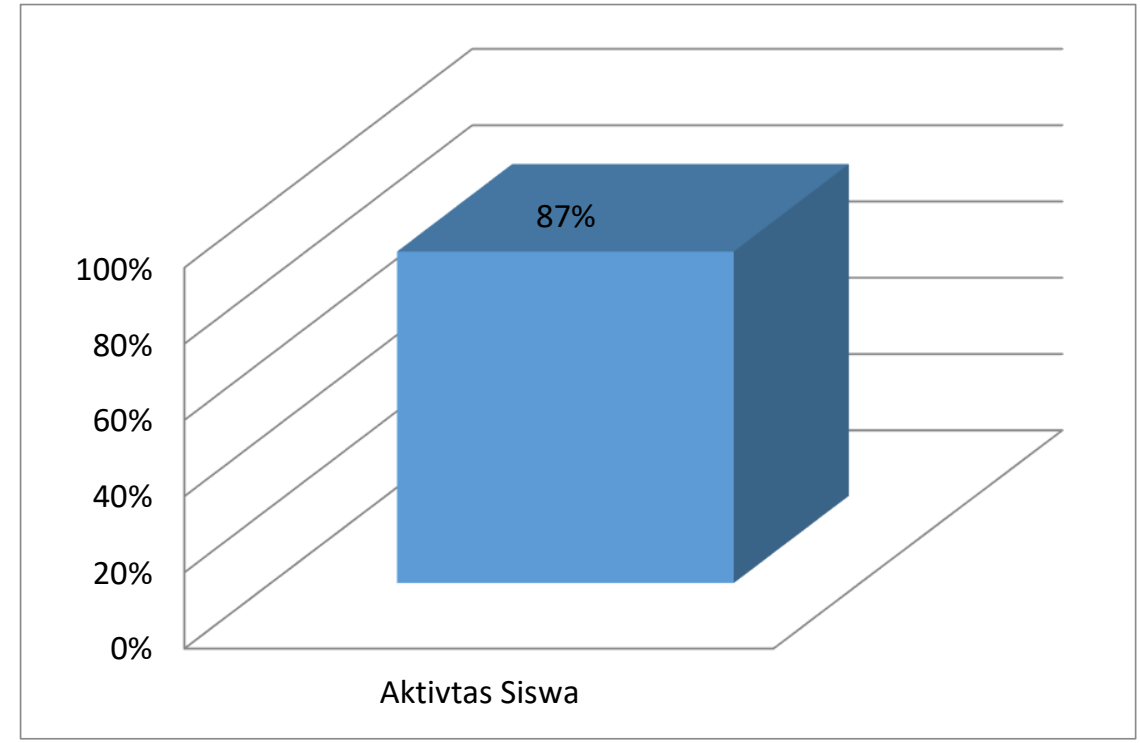

Grafik 7. Grafik Persentase Aktivitas Siswa Siklus II Tindakan 1

$$
\begin{aligned}
\text { Nilai rata-rata }(\mathrm{NR})= & \frac{\text { skor yang diperoleh }}{\text { Skor maksimal }} \times 100 \% \\
& =\frac{34}{40} \times 100 \%=87 \%
\end{aligned}
$$

Persentase aktivitas guru pada siklus II tindakan 2 dapat dilihat pada grafik berikut:

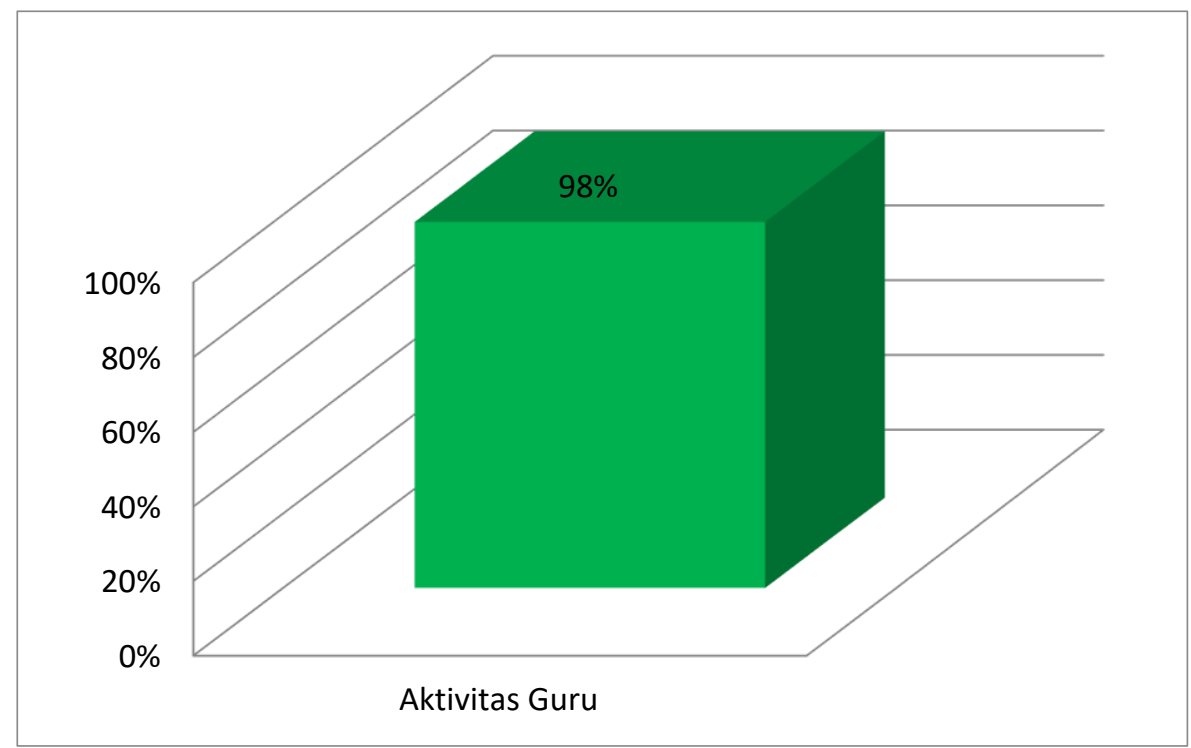

Grafik 8. Grafik Persentase Aktivitas Guru Siklus II Tindakan 2

Nilai rata-rata $(\mathrm{NR}) \quad=\frac{\text { skor yang diperoleh }}{\text { Skor maksimal }} \times 100 \%$

$$
=\frac{75}{76} \times 100 \%=98 \%
$$


Persentase aktivitas siswa pada siklus II tindakan 2 dapat dilihat pada grafik berikut:

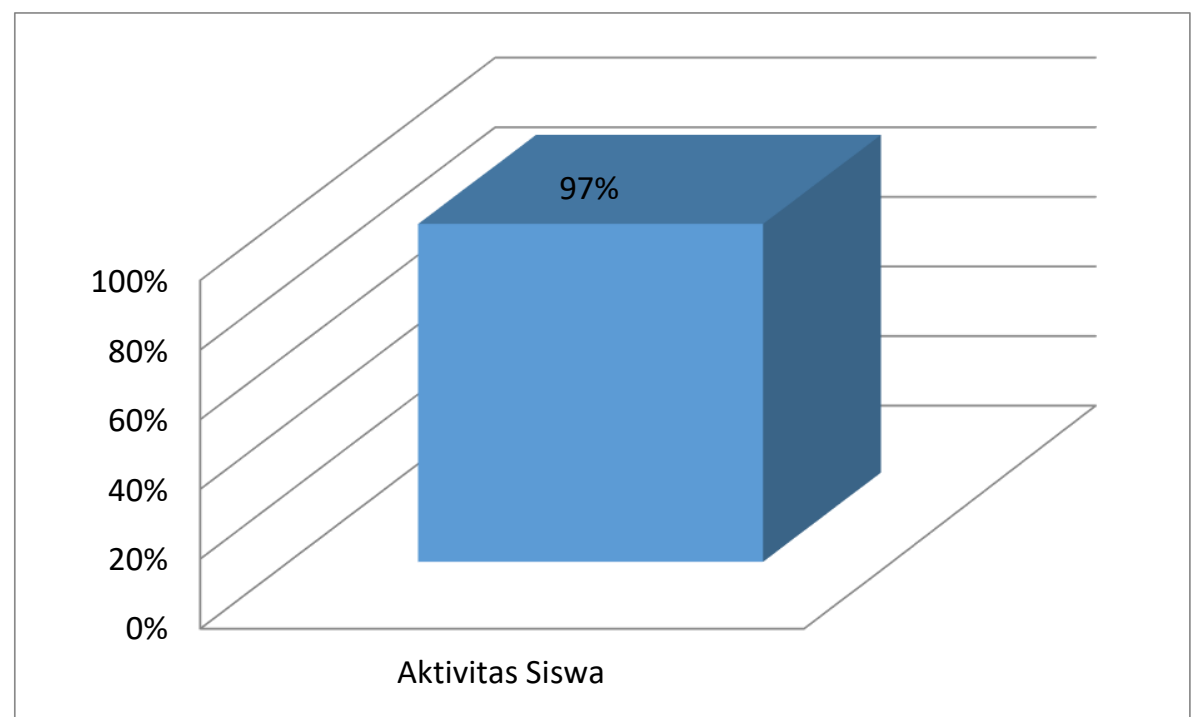

Grafik 9. Grafik Persentase Aktivitas Siswa Siklus II Tindakan 2

$$
\begin{aligned}
\text { Nilai rata-rata }(\mathrm{NR}) \quad= & \frac{\text { skor yang diperoleh }}{\text { Skor maksimal }} \times 100 \% \\
& =\frac{39}{40} \times 100 \%=97 \%
\end{aligned}
$$

Berdasarkan penjelasan di atas, dapat dilihat bahwa aktivitas guru dan aktivitas siswa mengalami peningkatan pada setiap tindakan dan siklusnya. Nilai rata-rata aktivitas guru dan aktivitas siswa pada setiap siklusnya dapat dilihat pada tabel berikut:

Tabel 6. Nilai rata-rata Aktivitas Guru dan Aktivitas Siswa Tiap Siklus

\begin{tabular}{|c|c|c|}
\hline Aktivitas Pembelajaran & Siklus I & Siklus II \\
\hline Aktivitas Guru & $72 \%$ (Sangat Baik) & $94 \%$ (Sangat Baik) \\
\hline Aktivitas Siswa & $67 \%$ (Baik) & $92 \%$ (Sangat Baik) \\
\hline
\end{tabular}

Adapun persentase nilai rata-rata aktivitas guru dan aktivitas siswa dengan menggunakan model cooperative learning tipe tebak kata dapat dilihat pada gambar grafik berikut: 


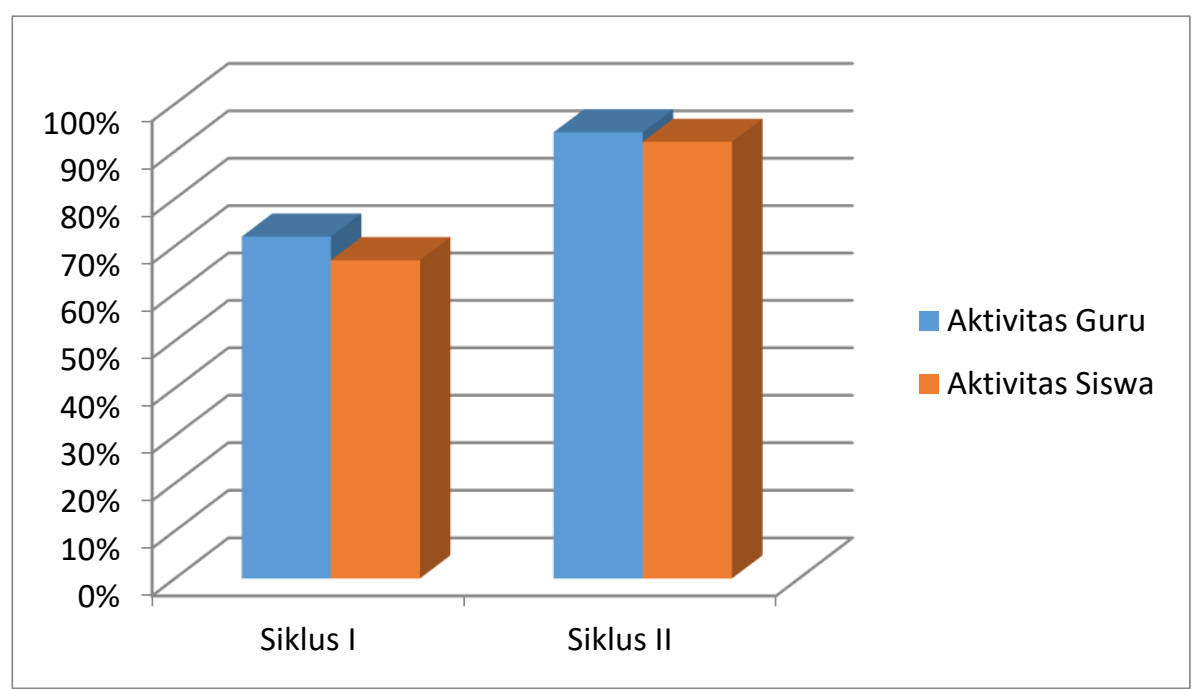

Grafik 10. Grafik Peningkatan Aktivitas Guru dan Aktivitas Siswa tiap Siklus

Berdasarkan grafik 10 dan tabel 6 diperoleh persentase rata-rata aktivitas guru pada siklus I sebesar $72 \%$ dengan kriteria sangat baik dan aktivitas siswa sebesar $67 \%$ dengan kriteria baik. Kemudian meningkat pada siklus II dengan perolehan persentase rata-rata aktivitas guru sebesar $94 \%$ dengan kriteria sangat baik dan aktivitas siswa sebesar 92\% dengan kriteria sangat baik.

c. Hasil Belajar Kognitif Siswa Pada Mata Pelajaran Sesudah Menggunakan Model Cooperative Learning Tipe Tebak Kata

Hasil belajar kognitif siswa pada mata pelajaran bahasa Arab dengan menggunakan model cooperative learning tipe tebak kata mengalami peningkatan pada setiap siklus dibandingkan hasil belajar kognitif siswa sebelum menggunakan model cooperative learning tipe tebak kata. Untuk mengetahui hasil belajar kognitif siswa pada mata pelajaran bahasa Arab meningkat atau tidaknya, maka guru memberikan tes berupa tes pilihan ganda yang diberikan sebanyak 10 butir pada setiap akhir siklus. Hasil belajar kognitif siswa pada siklus I mengalami peningkatan dari sebelumnya. Namun, hasil belajar kognitif siswa pada siklus I dianggap belum berhasil karena meskipun nilai rata-rata sudah termasuk kriteria cukup. Tapi masih ada beberapa siswa yang nilainya masih dibahwa nilai kriteria ketuntasan minimal mata pelajaran bahasa Arab yang telah ditentukan yaitu 65. Untuk memperbaiki hasil belajar kognitif siswa yang masih kurang optimal maka dilanjutkan pada siklus II.

Pada siklus II hasil belajar kognitif siswa pada mata pelajaran bahasa Arab mengalami peningkatan yang signifikan. Hal ini dapat dilihat dari nilai hasil belajar kognitif siswa yang sudah berada di atas nilai KKM yang telah ditentukan dan hanya satu orang saja yang belum mencapai nilai KKM. Berdasarkan hal tersebut penerapan model cooperative learning tipe tebak kata pada siklus II meningkat menjadi lebih baik dan hasil belajar kognitif siswa pada mata pelajaran bahasa Arab di kelas III MI Nurul Huda Kota Bandung dapat ditingkatkan, sehingga ketuntasan belajar siswa sesuai yang diharapkan. Peningkatan yang dihasilkan setelah penerapan model cooperative learning tipe tebak kata pada setiap siklusnya menunjukan peningkatan yang sangat baik, maka dapat disimpulkan dengan menggunakan model cooperative learning tipe tebak kata dapat meningkatkan hasil belajar kognitif pada mata pelajaran bahasa Arab. 
Tabel 7. Ketuntasan hasil belajar kognitif siswa Siklus I

\begin{tabular}{|c|c|c|}
\hline Persentase & Jumlah Siswa & Kriteria \\
\hline Siswa yang bernilai $\geq 65$ & 19 orang & Tuntas \\
\hline Siswa yang bernilai $\leq 65$ & 3 orang & Tidak tuntas \\
\hline
\end{tabular}

Adapun presentase hasil belajar kognitif siswa Siklus I dapat dilihat dalam bentuk diagram, pada gambar 2 sebagai berikut:

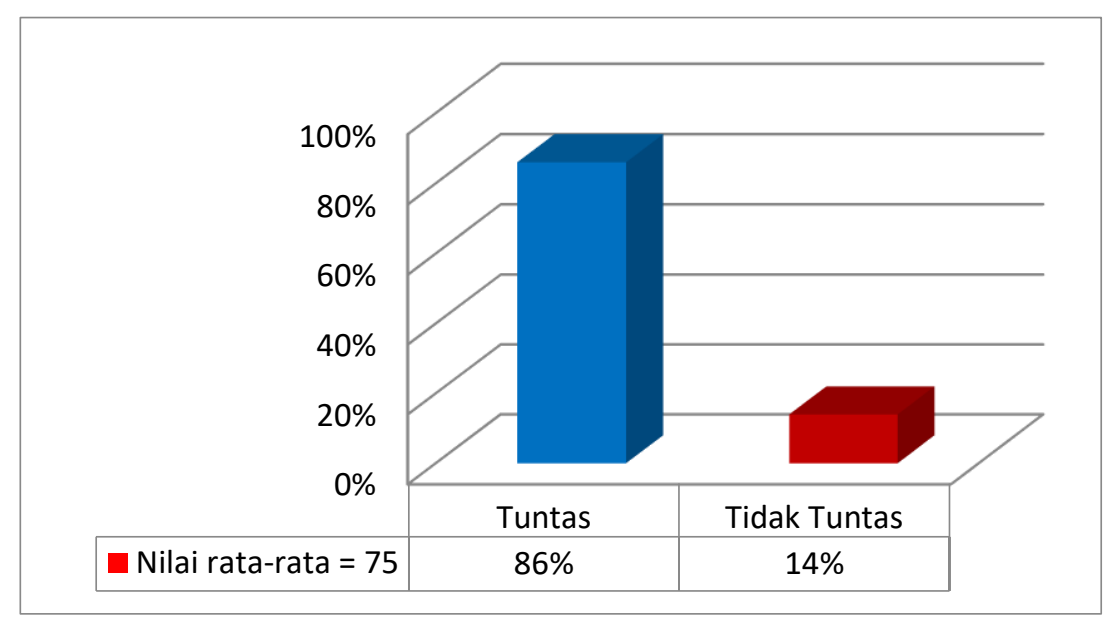

Grafik 11. Grafik Presentase Hasil Belajar Kognitif Siklus I

Berdasarkan Tabel 7 dan Grafik 11 menunjukan bahwa hasil belajar kognitif siswa dengan menggunakan model cooperative learning tipe tebak kata siklus I memperoleh nilai rata-rata sebesar 75 dengan persentase $86 \%$ dengan kriteria tuntas dan $14 \%$ dengan kriteria tidak tuntas. Berdasarkan hal tersebut maka hasil belajar kognitif siswa mengalami peningkatan dari sebelumnya.

Tabel 8. Ketuntasan hasil belajar kognitif siswa Siklus II

\begin{tabular}{|c|c|c|}
\hline Persentase & Jumlah Siswa & Kriteria \\
\hline Siswa yang bernilai $\geq 65$ & 21 orang & Tuntas \\
\hline Siswa yang bernilai $\leq 65$ & 1 orang & Tidak tuntas \\
\hline
\end{tabular}

Adapun presentase hasil belajar kognitif siswa Siklus II dapat dilihat dalam bentuk diagram, pada gambar 4 sebagai berikut: 


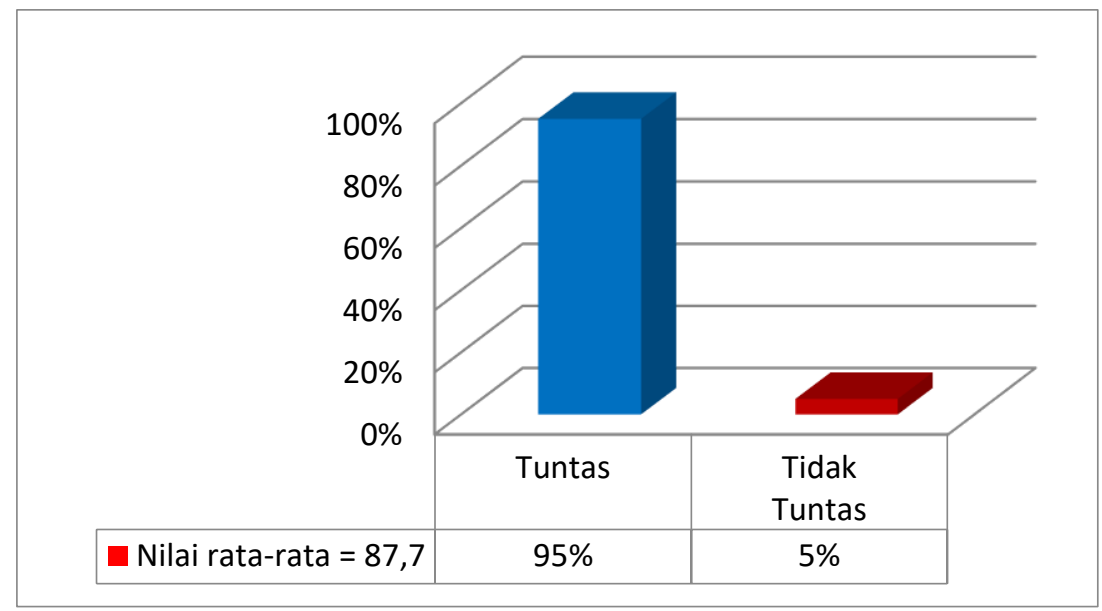

Grafik 12. Grafik Presentase Hasil Belajar Kognitif Siklus II

Berdasarkan Tabel 8 dan Grafik 12 menunjukan bahwa hasil belajar kognitif siswa dengan menggunakan model cooperative learning tipe tebak kata siklus II memperoleh nilai rata-rata sebesar 87,7 dengan persentase $95 \%$ dengan kriteria tuntas dan $5 \%$ dengan kriteria tidak tuntas. Berdasarkan hasil belajar kognitif siswa dalam pembelajaran bahasa Arab kelas III MI Nurul Huda Kota Bandung melalui penggunaan model cooperative learning tipe tebak kata berhasil meningkatkan hasil belajar kognitif siswa. Hal ini ditunjukan oleh peningkatan hasil belajar kognitif siswa pada setiap siklus.

\section{KESIMPULAN}

Berdasarkan hasil penelitian yang diperoleh dapat disimpulkan sebagai berikut: 1) hasil belajar kognitif siswa sebelum menggunakan model cooperative learning tipe tebak kata masih rendah yaitu dengan nilai rata-rata 54,09 dengan ketuntasan belajar 27\%. 2) penerapan model cooperative learning tipe tebak kata dalam setiap siklusnya mengalami peningkatan yaitu pada siklus I aktivitas guru sebesar $72 \%$ dengan kriteria sangat baik dan aktivitas siswa sebesar 67\% dengan kriteria baik. Sedangkan pada siklus II aktivitas guru sebesar 94\% dengan kriteria sangat baik dan aktivitas siswa sebesar 92\% dengan kriteria sangat baik. 3) hasil belajar kognitif siswa sesudah menggunakan model cooperative learning tipe tebak kata mengalami peningkatan pada setiap siklusnya. Siklus I diperoleh nilai rata-rata sebesar 75 dengan ketuntasan belajar 86\%, sedangkan pada siklus II diperoleh nilai rata-rata sebesar 87,7 dengan ketuntasan belajar 95\%. Berdasarkan data tersebut, dapat disimpulkan bahwa pembelajaran dengan menggunakan model coopertaive learning tipe tebak kata dapat meningkatkan hasil belajar kognitif siswa kelas III MI Nurul Huda Kota Bandung pada mata pelajaran bahasa Arab .

\section{BIBLIOGRAPHY}

Hasbullah. (2005). Dasar-dasar Ilmu Pendidikan. Jakarta: PT. Raja Grafindo Persada. Hayati, T. (2013). Evaluasi Pembelajaran. Bandung: CV. Insan Mandiri.

Ferianti, Fera. (2016). Penerapan Model Pembelajaran Model Cooperative Learning Tipe Tebak Kata Pada Mata Pelajaran Bahasa Arab Pulau Beringin Kabupaten Oku Selatan. Retrieved from https://www.eprints.radenfatah.ac.id/id/eprint/360

Hindun, Nurul. (2015). Penerapan Model Coopeartive Learning Tipe Number Heads Together (NHT) Untuk Meningkatkan Hasil Belajar Kognitif Siswa Pada Mata 
Pelajaran Sejarah Kebudayaan Islam Pokok Bahasan Mengenal Peristiwa Kerasulan Nabi Muhammad SAW Pada Kelas III MI Yapinur Limbangan-Garut. Unpublished. UIN Bandung.

Isjoni. (2010). Model Cooperative Learning. Bandung: ALFABETA.

Keputusan Menteri Agama (KMA) No.165 Tahun 2014 Kurma K13.pdf.

Rusman. (2010). Model-Model Pembelajaran Mengembangkan Profesionalisme Guru. Jakarta: Rajawali Pers.

Said, A \& Budimanjaya, A. (2015). 95 Startegi Mengajar Multiple Intelligences. Jakarta: Prenada Media Group.

Suprijono, A. (2009). Cooperative Learning. Yogyakarta: Pustaka Pelajar.

Susilawati, W. (2010). Pendidikan Matematika. Bandung: UIN Bandung.

Taniredja, T. (2014). Model-Model Pembelajaran Inovatif dan Efektif. Bandung: Alfabeta.

Trianto. (2013). Model Pembelajaran Terpadu. Jakarta: PT. Bumi Aksara. 